\title{
Effects of Croton rhamnifolioides Essential Oil on Aedes aegypti Oviposition, Larval Toxicity and Trypsin Activity
}

\author{
Geanne K. N. Santos ${ }^{1}$, Kamilla A. Dutra ${ }^{1}$, Camila S. Lira ${ }^{1}$, Bheatriz N. Lima ${ }^{1}$, \\ Thiago H. Napoleão ${ }^{2}$, Patrícia M. G. Paiva ${ }^{2}$, Claudia A. Maranhão ${ }^{3}$, Sofia S. F. Brandão ${ }^{3}$ and \\ Daniela M. A. F. Navarro ${ }^{1, *}$
}

1 Laboratório de Ecologia Química, Departamento de Química Fundamental, Universidade Federal de Pernambuco, 50670-901 Recife, PE, Brazil

2 Laboratório de Glicoproteínas, Departamento de Bioquímica, Universidade Federal de Pernambuco, 50670-420 Recife, PE, Brazil

3 Laboratório de Pesquisa e Desenvolvimento de Produtos Tecnológicos, Instituto Federal de Educação, Ciência e Tecnologia de Pernambuco, 50740-540 Recife, PE, Brazil

* Author to whom correspondence should be addressed; E-Mail: dmafn@ufpe.br; Tel.: +55-81-2126-7468; Fax: +55-81-2126-8442.

External Editor: Nancy D. Turner

Received: 17 July 2014; in revised form: 15 September 2014 / Accepted: 26 September 2014 / Published: 14 October 2014

\begin{abstract}
Although numerous reports are available concerning the larvicidal potential of essential oils, very few investigations have focused on their mechanisms of action. In the present study, we have investigated the chemical composition of the leaf oil of Croton rhamnifolioides during storage and its effects on oviposition and survival of larvae of the dengue fever mosquito Aedes aegypti. In addition, we have established a possible mechanism of action for the larvicidal activity of the essential oil. GC-MS analyses revealed marked differences in the composition of oil that had been freshly isolated and that of a sample that had been stored in a sealed amber-glass vial under refrigeration for three years. However, both fresh and stored oil exhibited substantial larvicidal activities with LC50 values of 122.35 and $89.03 \mathrm{ppm}$, respectively, and oviposition deterrent effects against gravid females at concentrations of 50 and $100 \mu \mathrm{g} \cdot \mathrm{mL}^{-1}$. These results demonstrate that the larvicidal effect of the essential oil was unchanged during three years of storage even though its chemical composition altered. Hence, the essential oil could be used in the preparation of commercial products. In addition, we observed that the trypsin-like activity of mosquito larvae was
\end{abstract}


inhibited in vitro by the essential oil of $C$. rhamnifolioides, suggesting that the larvicidal effect may be associated with inhibition of this enzyme.

Keywords: Aedes aegypti; Croton rhamnifolioides; essential oil; storage; oviposition deterrent

\section{Introduction}

Croton is a major genus of the family Euphorbiaceae and comprises some 1200 species of trees, shrubs and herbs that are widely distributed in tropical regions [1]. Members of the genus have been used in traditional medicine to treat a wide range of disorders, including malaria, inflammation, diabetes and cancer [2]. The biological properties of various Croton species have been investigated in laboratory studies involving murine models [3-10]. The chemical composition of Croton is somewhat diverse, although alkaloids [11,12], diterpenoids [13,14] and volatile oils comprising mono- and sesquiterpenoids [15-18], have been commonly reported.

In Brazil, some 356 species of Croton have been described [1] and these are distributed throughout the country in all biomes ranging from the tropical Amazon and Atlantic forests to the semi-arid northeastern regions [19]. Croton rhamnifolioides Pax \& K. Hoffm. has been identified in several areas of the Brazilian Caatinga [20], a biome that is characterized by high temperatures with long and irregular periods of drought. This xerophytic shrub is used in folk medicine to treat stomach disorders, vomiting, hemorrhagic diarrhea and fever [21]. The pleasant aroma of the species is reportedly due to the presence of terpenoids in all parts of the plant [22], while the leaves are rich in flavonoids, and the roots and bark contain predominantly alkaloids, triterpenoids and steroids. However, studies regarding the biological activity of $C$. rhamnifolioides are scarce.

In recent years, dengue fever and dengue hemorrhagic fever have become a public health concern in a number of countries, especially in South America and Asia. According to the World Health Organization [23], approximately 2.5 billion people live in countries that are endemic for dengue and some 50-million dengue infections occur every year. In the absence of effective prophylactics or vaccines against the disease, the prevention of dengue fever is restricted to controlling the principal vector Aedes (Stegomyia) aegypti (Linneus, 1762).

Management of the mosquito typically involves the use of synthetic organic insecticides, however, continuous application of these compounds has led to the development of resistant populations of A. aegypti [24-29]. For this reason, considerable research has focused on the use of plant natural products in the control of various mosquito vectors including A. aegypti [30-35]. Although essential oils are present in different parts of the plant, there is particular interest in their extraction from aerial parts because of the possibility of sustainable production. The larvicidal effects of essential oils from several plant species have been studied. For example, Navarro et al. [36] demonstrated that the leaf oils obtained from members of the families Lauraceae and Piperaceae exhibited strong larvicidal activities ( $\mathrm{LC}_{50}$ below 20 and $50 \mathrm{ppm}$, respectively). It has been accepted in the literature that an essential oil is active against A. aegypti larvae when $\mathrm{LC}_{50}<100 \mathrm{ppm}$ and strongly active when $\mathrm{LC}_{50}<50 \mathrm{ppm}$.

The present paper aimed to (i) determine the chemical composition of the essential oil from leaves of $C$. rhamnifolioides and (ii) assess the influence of storage on the biological activities of 
the $C$. rhamnifolioides essential oil against $A$. aegypti. The potential use of the leaf oil from C. rhamnifolioides in controlling the spread of $A$. aegypti is described for the first time together with a possible mechanism of action.

\section{Results and Discussion}

The yield of essential oil obtained by hydrodistillation of dried leaves of $C$. rhamnifolioides was $0.80 \%(\mathrm{w} / \mathrm{w})$, a value that is comparable with those reported previously for other species of Croton found in northeastern Brazil. For example, hydrodistillation of dried leaves of $C$. heliotropiifolius and C. pulegiodorus produced $0.2 \%$ and $5 \%$ of oil, respectively [37], while fresh branches of C. adamantinus gave $0.6 \%$ of oil [10] and fresh leaves and branches of $C$. campestris yielded $0.04 \%$ and $0.02 \%$ of oil, respectively [18]. Additionally, Camurça-Vasconcelos et al. [38] reported a 3.15\% yield of essential oil following steam distillation of the dried aerial parts of C. zehntneri.

A total of 57 compounds, mainly mono- and sesquiterpenoids, were identified by GC-MS analysis of the freshly isolated essential oil of $C$. rhamnifolioides (Table 1), and these components represented more than $92 \%$ of the total oil. The major constituent of the oil was the oxygenated sesquiterpene sesquicineole (16.79\%), followed by the monoterpene $\alpha$-phellandrene $(12.83 \%)$, the oxygenated monoterpene 1,8-cineole (7.24\%), and the sesquiterpene $(E)$-caryophyllene $(6.33 \%)$. The characteristic features of the essential oil of $C$. rhamnifolioides obtained in the present study resembled those reported for various species of Croton, including C. heliotropiifolius and C. pulegiodorus [37], C. argyrophylloides and C. sonderianus [39], C. nepetaefolius [40], C. adamantinus [10], and C. campestris [18], but differed from those of C. zehntneri, C. nepetaefolius [39] and C. regelianus [41], the major components of which were trans-anethole, methyl eugenol and ascaridole, respectively.

The chemical composition of an essential oil can change after extraction depending on the storage conditions applied. Misharina and co-workers [42] reported that storage of the essential oil of marjoram in the dark for one year resulted in insignificant alterations in composition, while considerable changes were detected in samples of the same oil that had been exposed to light during storage. In the present study, the essential oil of $C$. rhamnifolioides was stored in a sealed amber-glass vial maintained at $-5{ }^{\circ} \mathrm{C}$ for three years, conditions that have previously been shown to produce the smallest changes in the quality of volatile oil samples [43]. GC-MS analysis of the composition of the stored essential oil revealed that the relative percentages of 1,8-cineole (18.61\%) and $o$-cymene (14.64\%) had increased during storage, while that of sesquicineole $(1.77 \%)$ had decreased. In contrast, the relative concentration of $\alpha$-phellandrene was similar in both fresh and stored oil samples, and this prompted us to assess the larvicidal activity of this monoterpene hydrocarbon.

The observed increases in the relative percentages of oxygenated monoterpenes in the stored oil are in agreement with the findings of Turek et al. [44]. These authors also reported alterations in the amounts of $p$-cymene in essential oils submitted to different storage conditions, which were similar to those observed for $o$-cymene in the present study. Interestingly, 1,8-cineole and sesquicineole (Scheme 1) have similar biosynthetic pathways $[45,46]$ and so the increase in the amount of 1,8 -cineole requires careful investigation in future work. 
Table 1. Volatile compounds identified in fresh and stored samples of essential oil from Croton rhamnifolioides.

\begin{tabular}{|c|c|c|c|c|c|}
\hline Component $^{\mathrm{a}}$ & $\begin{array}{c}\text { Fresh Oil } \\
{[\%]}\end{array}$ & $\begin{array}{c}\text { LRI } \\
\text { calc. }^{b}\end{array}$ & $\begin{array}{c}\text { Stored Oil } \\
{[\%]}\end{array}$ & $\begin{array}{c}\text { LRI } \\
\text { calc. }^{b}\end{array}$ & $\begin{array}{l}\text { LRI } \\
\text { Lit. }^{c}\end{array}$ \\
\hline Tricyclene & 0.16 & 921 & 0.52 & 920 & 920 \\
\hline$\alpha$-Thujene & 1.49 & 924 & 2.17 & 926 & 926 \\
\hline$\alpha$-Pinene & 4.74 & 932 & 9.52 & 932 & 932 \\
\hline Camphene & 0.65 & 946 & 2.4 & 946 & 946 \\
\hline Sabinene & 3.04 & 969 & 7.18 & 972 & 972 \\
\hline$\beta$-Pinene & 0.55 & 974 & 0.69 & 974 & 974 \\
\hline Myrcene & 0.36 & 988 & 0.68 & 991 & 991 \\
\hline$\alpha$-Phellandrene & 12.83 & 1002 & 8.37 & 1003 & 1003 \\
\hline$\alpha$-Terpinene & 0.31 & 1014 & - & - & 1016 \\
\hline$o$-Cymene & 4.60 & 1022 & 14.64 & 1023 & 1023 \\
\hline Sylvestrene & 3.62 & 1025 & 3.99 & 1028 & 1027 \\
\hline 1,8-Cineole & 7.24 & 1026 & 18.61 & 1030 & 1030 \\
\hline Benzyl alcohol & 0.20 & 1026 & - & - & 1033 \\
\hline$(E)-\beta$ Ocimene & 0.75 & 1044 & 0.34 & 1049 & 1048 \\
\hline$\gamma$-Terpinene & 1.09 & 1054 & - & - & 1058 \\
\hline Terpinolene & 0.24 & 1086 & - & - & 1088 \\
\hline Linalool & 1.32 & 1095 & 1.27 & 1100 & 1100 \\
\hline Dehydro-sabina ketone & 0.16 & 1117 & - & - & 1120 \\
\hline$(Z)-\beta$-Terpineol & 0.08 & 1140 & - & - & 1139 \\
\hline Camphor & 0.06 & 1141 & 0.45 & 1144 & 1144 \\
\hline Pinocarvone & 0.02 & 1160 & - & - & 1162 \\
\hline Borneol & 0.83 & 1165 & - & - & 1165 \\
\hline Terpinen-4-ol & 1.90 & 1174 & 0.48 & 1177 & 1177 \\
\hline$\alpha$-Terpineol & 1.91 & 1186 & 0.7 & 1190 & 1190 \\
\hline Myrtenol & 0.31 & 1194 & - & - & 1196 \\
\hline Methyl chavicol & 0.06 & 1195 & - & - & 1198 \\
\hline Thymol methyl ether & 0.03 & 1232 & - & - & 1235 \\
\hline Bornyl acetate & 0.33 & 1284 & 0.72 & 1287 & 1286 \\
\hline Thymol & 0.05 & 1289 & - & - & 1292 \\
\hline Carvacrol & 0.20 & 1298 & - & - & 1301 \\
\hline Myrtenyl acetate & 0.02 & 1324 & - & - & 1326 \\
\hline$\delta$-Elemene & 0.03 & 1335 & - & - & 1338 \\
\hline$\alpha$-Copaene & 0.19 & 1374 & 0.43 & 1378 & 1377 \\
\hline$\beta$-Bourbonene & 0.07 & 1387 & - & - & 1386 \\
\hline$\beta$-Elemene & 0.35 & 1389 & 1.36 & 1394 & 1393 \\
\hline$(Z)$ - $\alpha$-Bergamotene & 0.05 & 1411 & - & - & 1417 \\
\hline (E)-Caryophyllene & 6.33 & 1417 & 4.37 & 1422 & 1422 \\
\hline (E) $\alpha$-Bergamotene & 0.14 & 1432 & - & - & 1438 \\
\hline$(Z)-\beta$-Farnesene & 0.04 & 1440 & - & - & 1445 \\
\hline
\end{tabular}


Table 1. Cont.

\begin{tabular}{|c|c|c|c|c|c|}
\hline Component $^{a}$ & $\begin{array}{c}\text { Fresh Oil } \\
{[\%]}\end{array}$ & LRI calc. ${ }^{b}$ & $\begin{array}{c}\text { Stored } \\
\text { Oil [\%] }\end{array}$ & $\begin{array}{c}\text { LRI } \\
\text { calc. }^{b}\end{array}$ & $\begin{array}{l}\text { LRI } \\
\text { Lit. }^{c}\end{array}$ \\
\hline$\alpha$-Humulene & 1.17 & 1452 & 0.96 & 1456 & 1457 \\
\hline 9-epi-(E)-Caryophyllene & 0.80 & 1464 & 0.95 & 1464 & 1465 \\
\hline$\gamma$-Muurolene & 0.04 & 1478 & - & - & 1481 \\
\hline Germacrene D & 0.99 & 1484 & - & - & 1485 \\
\hline Viridiflorene & 0.14 & 1496 & 0.71 & 1489 & 1490 \\
\hline Bicyclogermacrene & 4.59 & 1500 & 2.44 & 1499 & 1501 \\
\hline (Z)- $\beta$-Guaiene & 0.10 & 1502 & - & - & 1504 \\
\hline$\alpha$-Bulnesene & 0.05 & 1509 & - & - & 1506 \\
\hline Germacrene A & 0.21 & 1508 & 0.84 & 1508 & 1510 \\
\hline Sesquicineole & 16.79 & 1515 & 1.77 & 1516 & 1518 \\
\hline$\delta$-Cadinene & 0.45 & 1522 & 0.44 & 1526 & 1527 \\
\hline Germacrene B & 0.06 & 1559 & - & - & 1556 \\
\hline Spathulenol & 4.14 & 1577 & 4.98 & 1580 & 1580 \\
\hline Caryophyllene oxide & 3.22 & 1582 & 2.89 & 1586 & 1586 \\
\hline Viridiflorol & 0.09 & 1592 & - & - & 1596 \\
\hline epi- $\alpha$-Cadinol & 2.33 & 1638 & 3.16 & 1644 & 1643 \\
\hline$\alpha$-Bisabolol & 0.72 & 1685 & - & - & 1685 \\
\hline Eudesma-4(15),7-dien-1 $\beta$-ol & 0.23 & 1687 & - & - & 1688 \\
\hline Monoterpene hydrocarbons & 32.94 & & 48.33 & & \\
\hline Oxygenated monoterpenes & 15.85 & & 24.4 & & \\
\hline Sesquiterpene hydrocarbons & 15.75 & & 12.5 & & \\
\hline Oxygenated sesquiterpenes & 27.52 & & 12.8 & & \\
\hline Total & 92.47 & & & 98.03 & \\
\hline
\end{tabular}

${ }^{a}$ Constituents listed in order of elution from a non-polar DB-5 capillary column; ${ }^{b}$ Linear retention indices calculated from retention times in relation to those of a series of $n$-alkanes separated on a non-polar DB-5 capillary column; ${ }^{\mathrm{c}}$ Linear retention indices from the literature.

Scheme 1. Chemical structures of 1,8-cineole and sesquicineole.

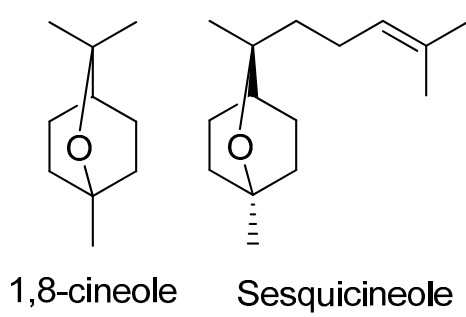

With the aim of developing novel methods for the control of $A$. aegypti populations, the larvicidal activities of samples of essential oils obtained from dried leaves of $C$. rhamnifolioides were evaluated. Both fresh and stored samples of the essential oil exhibited substantial larvicidal activity against 4th instar A. aegypti $\left(\mathrm{LC}_{50}=122.3 \pm 3.7\right.$ and $89.03 \pm 1.94 \mu \mathrm{g} \cdot \mathrm{mL}^{-1}$, respectively; Table 2$)$. The larvicidal properties of sesquicineole, one of the four major components of the fresh oil, could not be assayed directly because the standard compound was not available commercially. However, since storage of the oil was associated with an increase in larvicidal activity but to a decrease in the amount of sesquicineole 
present, it is reasonable to assume that this constituent made little or no significant contribution to the overall larvicidal activity of the oil. On the other hand, bioassay of standard $\alpha$-phellandrene revealed strong activity against $A$. aegypti larvae with an $\mathrm{LC}_{50}$ value of $39.3 \pm 1.0 \mu \mathrm{g} \cdot \mathrm{mL}^{-1}$, while standard 1,8 cineole was not effective in killing larvae at concentrations below $150 \mu \mathrm{g} \cdot \mathrm{mL}^{-1}$. According to the literature, the contributions to larvicidal activity of 1,8-cineole ( $\mathrm{LC}_{50}$ in the range $74.9-1381 \mu \mathrm{g} \cdot \mathrm{mL}^{-1}$ ), $\alpha$-pinene $\left(\mathrm{LC}_{50}>300 \mu \mathrm{g} \cdot \mathrm{mL}^{-1}\right)$ and $(E)$-caryophyllene $\left(\mathrm{LC}_{50}\right.$ in the range $88.3-1202 \mu \mathrm{g} \cdot \mathrm{mL}^{-1}$ ) vary from moderate to low [36-47]. Moreover, our data relating to the larvicidal effect of $\alpha$-phellandrene are in agreement with the results published by Perumalsamy et al. [48] and Cheng et al. [49]. However, it is also possible that $o$-cymene might contribute to maintaining the larvicidal activity in stored samples of C. rhamnifolioides oil since, although larvicidal data for standard $o$-cymene are not available in the literature, the $\mathrm{LC}_{50}$ value for the isomer $p$-cymene is reportedly within the range 19.2 to $37.1 \mu \mathrm{g} \cdot \mathrm{mL}^{-1}$ [47].

Table 2. Larvicidal activities of fresh and stored samples of essential oil of Croton rhamnifolioides and their major constituents.

\begin{tabular}{|c|c|c|c|c|}
\hline Test Sample & $\begin{array}{l}\mathbf{L C}_{50} \pm \mathrm{SE} \\
{\left[\mu \mathrm{g} \cdot \mathrm{mL}^{-1}\right]}\end{array}$ & $\begin{array}{c}\text { Confidence Interval } \\
{\left[\mu \mathrm{g} \cdot \mathrm{mL}^{-1}\right]}\end{array}$ & $\mathrm{X}^{2}$ Test & $p$ Level \\
\hline $\begin{array}{l}\text { C. rhamnifolioides } \\
\text { (fresh essential oil) }\end{array}$ & $122.3 \pm 3.7$ & $115.1-129.6$ & 0.2 & 1.00 \\
\hline $\begin{array}{l}\text { C. rhamnifolioides } \\
\text { (stored essential oil) }\end{array}$ & $89.0 \pm 1.9$ & $85.2-92.8$ & 0.6 & 0.90 \\
\hline$\alpha$-Phellandrene & $39.3 \pm 1.0$ & $37.3-41.3$ & 1.4 & 0.77 \\
\hline 1,8-Cineole & $>100$ & - & - & - \\
\hline
\end{tabular}

Activities against A. aegypti larvae of essential oils derived from a number of Croton species have been reported in the literature. Thus, oils from C. zehntneri, C. nepetaefolius, C. argyrophyloides and C. sonderianus showed LC50 values of 28, 84, 102 and $104 \mu \mathrm{g} \cdot \mathrm{mL}^{-1}$, respectively, against 3rd instar A. aegypti [40]. Additionally, all of these oils exhibited ovicidal and pupicidal effects against the dengue vector [39]. Dória et al. [37] assayed essential oils from C. pulegiodorus and C. heliotropiifolius against larvae of $A$. aegypti and reported $\mathrm{LC}_{50}$ values of 159 and $544 \mu \mathrm{g} \cdot \mathrm{mL}^{-1}$, respectively. The essential oils from specimens of $C$. regelianus collected at two different locations in the Brazilian state of Ceará, were highly effective against $3 \mathrm{rd}$ instar $A$. aegypti (LC50 in the range 24.22 and $66.74 \mu \mathrm{g} \cdot \mathrm{mL}^{-1}$ ), and this activity was apparently associated with the major oil component ascaridole [41].

Although there are various reports on the larvicidal activity of essential oils against A. aegypti, the mechanisms of action are not yet understood. In this study, we tested the hypothesis that the leaf oil of $C$. rhamnifolioides may interfere with the trypsin-like activity of the larval gut. The results revealed that the leaf oil inhibited trypsin-like activity of 4th instar A. aegypti in a dose-dependent manner (Figure 1), and this inhibitory effect may be associated with larvicidal activity. Trypsin is a serine protease that occurs widely in insect guts and the impairment of its activity may result in poor nutrient absorption and non-availability of essential amino acids. Trypsin-like enzymes from $A$. aegypti larvae have been reported as targets for other plant-derived larvicides as exemplified by the trypsin inhibitor found in Moringa oleifera flowers [50] and the lectin detected in Myracrodruon urundeuva leaves [51]. 
Figure 1. Effect of the leaf oil of Croton rhamnifolioides on the trypsin-like activity of Aedes aegypti 4th instar larvae.

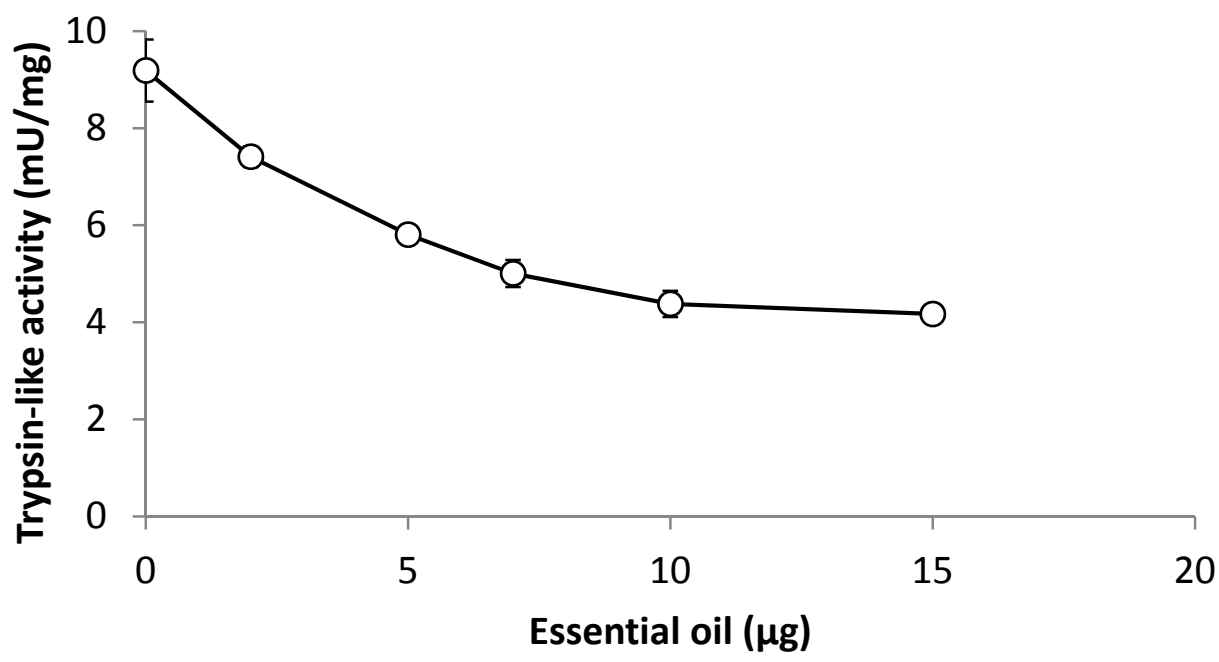

Other potential targets of essential oils are TRP-type ion channels, acetylcholinesterase and receptors of tyramine, octopamine and GABA [52]. Kostyukovsky et al. [53] found that essential oils from Israeli plants were able to activate octopaminergic receptors present in the abdominal segments of Helicoverpa armigera, while Enan [54] suggested that the toxicity of cinnamic alcohol, eugenol, trans-anethole, and 2-phenethyl propionate against Drosophila melanogaster is mediated by octopamine receptors. A molecular docking study conducted by Khanikor et al. [55] indicated that the terpenes carvacrol, eucalyptol and eugenol act as acetylcholinesterase inhibitors and bind to the octopamine receptors of A. aegypti. However, Anderson and Coats [56] demonstrated that the terpenoids carvacrol and nootkatone did not inhibit acetylcholinesterase in A. aegypti. Our study opens new windows on the mechanisms of action of essential oils against $A$. aegypti by reporting the inhibitory effect of $C$. rhamnifolioides oil on a digestive enzyme from larvae of this species.

The selection by gravid female mosquitoes of suitable sites for oviposition is guided by various factors including visual and olfactory cues. The presence of an oviposition deterrent in the water can result in the laying of few, if any, eggs at that site [57]. In the present study, aliquots of fresh and stored essential oils from $C$. rhamnifolioides exhibited an oviposition deterrent effect at 50 and $100 \mu \mathrm{g} \cdot \mathrm{mL}^{-1}$ with significantly smaller numbers of eggs $(<50 \%)$ being laid in vessels containing oil solutions compared with those containing a control solution (Figure 2 ).

It is reported that essential oils from a wide variety of species, including C. zehntneri, C. argyrophylloides [39], Piper marginatum [58] and Cananga odorata [59], exhibit oviposition deterrent properties similar to those reported in the present study.

\section{Experimental Section}

\subsection{Plant Material}

Specimens of $C$. rhamnifolioides were collected at a private farm located in the municipality of Serra Talhada, PE, Brazil, in October 2009. Plant material was identified by Dr. Elba Maria Nogueira Ferraz Ramos (Instituto Federal de Educação, Ciência e Tecnologia de Pernambuco, Recife, PE, Brazil), and a 
voucher specimen has been deposited at the Herbarium Vasconcelos Sobrinho, Universidade Federal Rural de Pernambuco, Recife, PE, Brazil, with voucher number 49,855.

Figure 2. Oviposition responses of gravid Aedes aegypti to aqueous solutions of fresh and stored samples of essential oil from Croton rhamnifolioides. The values represent mean percentages $( \pm \mathrm{SE})$ of the total eggs laid after $16 \mathrm{~h}$ in response to the treatment. Each assay involved ten mosquitoes and was replicated eight times.

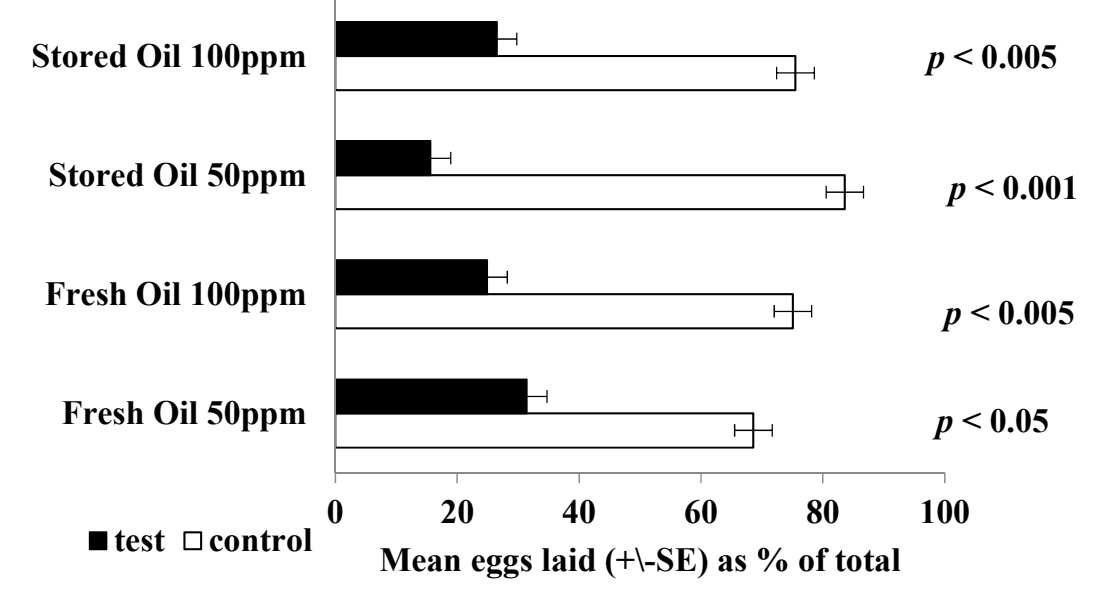

\subsection{Extraction of Essential Oil}

Leaves of $C$. rhamnifolioides were separated manually and left to dry naturally under shade conditions for three days. Dried leaves (100 g) were submitted to hydrodistillation with $1 \mathrm{~L}$ of distilled water for $2 \mathrm{~h}$ in a Clevenger-type apparatus, following which the essential oil layer was separated, dried over anhydrous sodium sulfate and transferred to amber-glass vials. The yield of fresh essential oil was determined as the quotient of the weight of oil collected and the dry weight of plant material extracted. The chemical composition and biological activity of the oil was measured soon after extraction (fresh oil) and after storage in a hermetically sealed amber-glass vial for three years at $-5^{\circ} \mathrm{C}$ (stored oil).

\subsection{GC-MS Analyses}

Analyses of fresh and stored samples of essential oils were carried out using an Agilent Technologies (Palo Alto, CA, USA) 5975C single quadrupole GC-MS equipped with a J \& WScientific non-polar DB-5 fused silica capillary column $(30 \mathrm{~m} \times 0.25 \mathrm{~mm}$ i.d.; film thickness $0.25 \mathrm{~mm})$. The oven was held initially at $60^{\circ} \mathrm{C}$ for $3 \mathrm{~min}$, then increased at $2.5^{\circ} \mathrm{C} \cdot \mathrm{min}^{-1}$ to $240{ }^{\circ} \mathrm{C}$, and finally held at this temperature for $10 \mathrm{~min}$. The carrier gas was helium supplied at a constant pressure of $100 \mathrm{kPa}$, and the split/splitless injector was maintained at $250^{\circ} \mathrm{C}$. The applied ionization potential was $70 \mathrm{eV}$, the scan range was from 40 to $350 \mathrm{~m} / z$ and the scan rate was $0.5 \mathrm{scans} \cdot \mathrm{s}^{-1}$. Samples $\left(1 \mu \mathrm{L}\right.$ containing $2 \mathrm{mg} \cdot \mathrm{mL}^{-1}$ of essential oil in hexane) were introduced onto the column with the injector in the splitless mode. Linear retention indices (LRI) were determined for the individual components of the essential oil by co-injection of a sample with a mixture of $\mathrm{C}_{8}-\mathrm{C}_{30}$ linear hydrocarbons under the conditions described above, and subsequent application of the Van den Dool and Kratz [60] equation. Constituents were initially identified by comparison of LRI values with those published in the literature, and the identities 
confirmed by matching acquired MS with those stored in the library of the GC-MS system (NIST, Gaithersburg, MD, USA and Wiley, New Jersey, NJ, USA) and with other published data [61].

\subsection{Mosquito Population}

A population of $A$. aegypti (Rockefeller strain) was maintained in the laboratory at $28 \pm 1{ }^{\circ} \mathrm{C}$ and $70 \% \pm 5 \%$ relative humidity under a $14 \mathrm{~h}$ photoperiod. Adult mosquitoes were reared in wooden cages $(33 \times 33 \times 33 \mathrm{~cm})$ and maintained on $10 \%$ sucrose solution, while females were blood-fed on pigeons once a week. Eggs were collected three days after the blood meal by placing a recipient, containing tap water and a piece of filter paper to provide support for oviposition, inside the cage. Eggs were hatched by submersion in tap water, and larvae were reared in plastic basins and fed on a diet of commercial cat food (Whiskas ${ }^{\circledR}$, Mars Petcare Corporate, Guararema, Brazil).

\subsection{Larvicidal Bioassays}

Bioassays were conducted soon after extraction of the essential oil (fresh oil) and after three years of storage at $-5{ }^{\circ} \mathrm{C}$ (stored oil). In both cases, a stock colloidal solution (containing $200 \mu \mathrm{g} \cdot \mathrm{mL}^{-1}$ ) was prepared by dissolving $20.00 \mathrm{mg}$ of oil sample in $1.4 \mathrm{~mL}$ of ethanol and completing to $100 \mathrm{~mL}$ with distilled water to produce a homogenous solution. Larvicidal activities were evaluated using the method recommended by the World Health Organization [23] as modified by Navarro et al. [62]. Early 4th instar larvae of $A$. aegypti (recognized by the lighter color of the head and pronota) were transferred to disposable cups (20 larvae per cup) containing essential oil at different concentrations prepared by dilution of the stock solution with distilled water. Five concentrations of oil solution (80, 100, 120, 140 and $160 \mu \mathrm{g} \cdot \mathrm{mL}^{-1}$ for fresh oil; 75, 80, 90, 100 and $120 \mu \mathrm{g} \cdot \mathrm{mL}^{-1}$ for stored oil) were assayed in order to determine median lethal concentration $\left(\mathrm{LC}_{50}\right)$ values, and four replicate assays were carried out for each sample concentration. For comparison purposes, bioassays were also performed with standard $\alpha$-phellandrene (SAFC: purity 99\%) at concentrations of $30,35,40,45$ and $50 \mu \mathrm{g} \cdot \mathrm{mL}^{-1}$, and with standard 1,8 cineole (Sigma-Aldrich: purity 99\%) at concentrations of 50, 100, 150 and $200 \mu \mathrm{g} \cdot \mathrm{mL}^{-1}$. Larval mortalities, assessed as lack of response to stimulus or larvae not rising to the surface, were determined after 24 and $48 \mathrm{~h}$, and $\mathrm{LC}_{50}$ values were calculated from $48 \mathrm{~h}$ mortality data by Probit analysis using StatPlus2008 software. Negative controls (distilled water containing the same amount of ethanol as the test sample) were included in each assay and the absence of larvae mortality was confirmed. An aqueous solution containing $1 \mu \mathrm{g} \cdot \mathrm{mL}^{-1}$ of Temephos, a commonly used larvicide, formed the positive control and $100 \%$ larvae mortality was verified.

\subsection{Gut Extracts from A. aegypti 4th Instar Larvae}

Groups of fifty 4 th instar larvae were collected and immobilized by cooling at $4{ }^{\circ} \mathrm{C}$ for $10 \mathrm{~min}$. The gut of each larva was subsequently removed using a needle ( $8 \mathrm{~mm}$ long; $0.3 \mathrm{~mm}$ diameter), transferred to a $2 \mathrm{~mL}$ tissue grinder and immediately homogenized with $1 \mathrm{~mL}$ of $0.1 \mathrm{M}$ Tris- $\mathrm{HCl}$ ( $\mathrm{pH} 8.0$ ) containing $0.02 \mathrm{M} \mathrm{CaCl}_{2}$ and $0.15 \mathrm{M} \mathrm{NaCl}$. The homogenate was centrifuged $\left(9000 \times g ; 4{ }^{\circ} \mathrm{C}\right.$, $15 \mathrm{~min}$ ) and the supernatant (gut extract) was collected and evaluated for protein concentration [63] and trypsin-like activity. 


\subsection{Effect of Leaf Oil on Trypsin-Like Activity from Larvae}

Trypsin-like activity was determined by incubating larval gut extract $(15 \mu \mathrm{L})$ for $30 \mathrm{~min}$ at $37^{\circ} \mathrm{C}$ with $8 \mathrm{mM} N$-benzoyl-DL-arginyl-p-nitroanilide (BApNA, $5 \mu \mathrm{L})$ in $0.1 \mathrm{M}$ Tris- $\mathrm{HCl} \mathrm{pH} 8.0(180 \mu \mathrm{L})$. Hydrolysis of the substrate was followed by measurement of the absorbance at $405 \mathrm{~nm}$ using a microplate reader ( $\mu$ Quant, MQX200; BioTek Instruments, Inc., Winooski, VT, USA). One unit of trypsin activity was defined as the amount of enzyme that hydrolyzes $1 \mu \mathrm{mol}$ of BApNA per min. Specific trypsin-like activity was defined as the ratio between enzyme activity and protein amount (mg) in the assay.

The effect of leaf oil on trypsin-like activity was determined according to Pontual et al. [50]. Larval gut extract $(15 \mu \mathrm{L})$ was incubated with the oil sample $(2.0$ to $15.0 \mu \mathrm{g}$ dissolved in dimethyl sulfoxide) for $10 \mathrm{~min}$ at $28{ }^{\circ} \mathrm{C}$, following which the substrate $(8 \mathrm{mM}$ BApNA; $5 \mu \mathrm{L})$ was added and the mixture incubated for a $45 \mathrm{~min}$ at $37{ }^{\circ} \mathrm{C}$ prior to measurement of the absorbance at $405 \mathrm{~nm}$. All assays were performed in triplicate along with the reaction blanks containing substrate or gut extract only.

\subsection{Oviposition Bioassays}

Solutions containing aliquots of fresh or stored essential oils at concentrations of 50 and $100 \mu \mathrm{g} \cdot \mathrm{mL}^{-1}$ were prepared by dissolving the appropriate amount of oil in $1.4 \mathrm{~mL}$ of ethanol and completing to $200 \mathrm{~mL}$ with distilled water. Ten gravid 7 day old $A$. aegypti females were transferred to a cage $(33 \times 21 \times 30 \mathrm{~cm})$ containing two disposable cups, one filled with $25 \mathrm{~mL}$ of essential oil solution and the other with $25 \mathrm{~mL}$ of control solution (distilled water containing the same amount of ethanol as the oil sample). Filter paper was placed on the internal surface of each cup to provide a support for oviposition, and the two cups were placed at diagonally opposite corners of the cage. For each treatment, eight cages were prepared. The bioassay was conducted in the dark for $16 \mathrm{~h}$ at $28 \pm 1{ }^{\circ} \mathrm{C}$ and $70 \% \pm 5 \%$ relative humidity. The oviposition response was subsequently determined by counting the numbers of eggs laid on the filter papers. Mean values obtained in each of the treatments were compared using the Student $t$-test $[58,62]$.

\section{Conclusions}

$\alpha$-Phellandrene and the essential oil of $C$. rhamnifolioides could find application in the control of A. aegypti, since both inhibit the oviposition of females at the breeding sites and kill mosquito larvae before they become adults. The retention of the larvicidal and oviposition deterrent activities of the essential oil during storage demonstrates that $C$. rhamnifolioides leaf oil could be used in the long term to combat the spread of the dengue mosquito. The mechanism of action of the leaf oil may be associated with its ability to inhibit trypsin-like activity in 4th instar larvae of $A$. aegypti.

\section{Acknowledgments}

The authors wish to thank FACEPE/PRONEX- APQ 0981-1.06/08 and INCT Dengue (CNPq and FAPEMIG) for financial assistance, and CNPq, CAPES and FACEPE for PhD and Masters fellowships. 


\section{Author Contributions}

D.M.A.F. Navarro conceived and designed the experiments; G.K.N. Santos, K.A. Dutra, C.S. Lira, B.N. Lima and D.M.A.F. Navarro were responsible for chemical analysis of the essential oils and for assessing their biological activities against Aedes aegypti; T.H. Napoleão and P.M.G. Paiva were responsible for the enzyme assays; C.A. Maranhão and S.S.F. Brandão were responsible for plant collection, oil isolation and deposition of the voucher specimen; D.M.A.F. Navarro, G.K.N. Santos and T.H. Napoleão drafted the manuscript. All authors read and approved the final manuscript.

\section{Conflicts of Interest}

The authors declare no conflict of interest.

\section{References}

1. Lima, L.R.; Pirani, J.R. Taxonomic revision of Croton sect. Lamprocroton (Müll. Arg.) Pax (Euphorbiaceae s.s.). Biota Neotrop. 2008, 8, 177-231.

2. Salatino, A.; Salatino, M.L.F.; Negri, G. Traditional uses, chemistry and pharmacology of Croton species (Euphorbiaceae). J. Braz. Chem. Soc. 2007, 18, 11-33.

3. Hiruma-Lima, C.A.; Gracioso, J.S.; Rodríguez, J.A.; Haun, M.; Nunes, D.S.; Souza Brito, A.R.M. Gastroprotective effect of essential oil from Croton cajucara Benth. (Euphorbiaceae). J. Ethnopharmacol. 2000, 69, 229-234.

4. Gurgel, L.A.; Silva, R.M.; Santos, F.A.; Martins, D.T.; Mattos, P.O.; Rao, V.S. Studies on the antidiarrhoeal effect of dragon's blood from Croton urucurana. Phytother. Res. 2001, 15, 319-322.

5. Appendino, G.; Borrelli, F.; Capasso, R.; Campagnuolo, C.; Fattorusso, E.; Petrucci, F.; Taglialatela-Scafati, O. Minor diterpenoids from cascarilla (Croton eluteriaBennet) and evaluation of the cascarilla extract and cascarillin effects on gastric acid secretion. J. Agric. Food Chem. 2003, $51,6970-6974$.

6. Nardi, G.M.; Felippi, R.; DalBó, S.; Siqueira-Junior, J.M.; Arruda, D.C.; Delle Monache, F.; Timbola, A.K.; Pizzolatti, M.G.; Ckless, K.; Ribeiro-do-Valle, R.M. Anti-inflammatory and antioxidant effects of Croton celtidifolius bark. Phytomedicine 2003, 10, 176-184.

7. Suárez, A.I.; Compagnone, R.S.; Salazar-Bookaman, M.M.; Tillett, S.; Delle Monache, F.; di Giulio, C.; Bruges, G. Antinociceptive and anti-inflammatory effects of Croton malambo bark aqueous extract. J. Ethnopharmacol. 2003, 88, 11-14.

8. Aguilar-Guadarrama, A.B.; Rios, M.Y. Three new sesquiterpenes from Croton arboreous. J. Nat. Prod. 2004, 67, 914-917.

9. Cavalcanti, J.M.; Leal-Cardoso, J.H.; Diniz, L.R.L.; Portella, V.G.; Costa, C.O.; Linard, C.F.B.M.; Alves, K.; Rocha, M.V.A.P.; Lima, C.C.; Cecatto, V.M.; et al. The essential oil of Croton zehntneri and trans-anethole improves cutaneous wound healing. J. Ethnopharmacol. 2012, 144, 240-247.

10. Ximenes, R.M.; Morais Nogueira, L.; Cassundé, N.M.R.; Jorge, R.J.B.; dos Santos, S.M.; Magalhães, L.P.M.; Silva, M.R.; Barros Viana, G.S.; Araújo, R.M.; de Sena, K.X.F.R.; et al. Antinociceptive and wound healing activities of Croton adamantinus Müll. Arg. essential oil. J. Nat. Med. 2013, 67, 758-764. 
11. Amaral, A.C.F.; Barnes, R.A. A tetrahydroprotoberberine alkaloid from Croton hemiargyreus. Phytochemistry 1998, 47, 1445-1447.

12. Milanowski, D.J.; Winter, R.E.K.; Elvin-Lewis, M.P.F.; Lewis, W.H. Geographic distribution of three alkaloid chemotypes of Croton lechleri. J. Nat. Prod. 2002, 65, 814-819.

13. Block, S.; Baccelli, C.; Tinant, B.; van Meervelt, L.; Rozenberg, R.; Habib Jiwan, J.-L.; Llabrès, G.; de Pauw-Gillet, M.-C.; Quetin-Leclercq, J. Diterpenes from the leaves of Croton zambesicus. Phytochemistry 2004, 65, 1165-1171.

14. Aguiar, L.A.; Porto, R.S.; Lahlou, S.; Ceccatto, V.M.; Barbosa, R.; Lemos, T.L.G.; dos Santos, H.S.; Coelho-de-Souza, A.N.; Magalhães, P.J.C.; Zin, W.A.; et al. Antispasmodic effects of a new kaurene diterpene isolated from Croton argyrophylloides on rat airway smooth muscle. J. Pharm. Pharmacol. 2012, 64, 1155-1164.

15. Fontenelle, R.O.S.; Morais, S.M.; Brito, E.H.S.; Brilhante, R.S.N.; Cordeiro, R.A.; Nascimento, N.R.F.; Kerntopf, M.R.; Sidrim, J.J.C.; Rocha, M.F.G. Antifungal activity of essential oils of Croton species from the Brazilian Caatinga biome. J. Appl. Microbiol. 2008, 104, 1383-1390.

16. Brasil, D.S.B.; Muller, A.H.; Guilhon, G.M.S.P.; Alves, C.N.; Andrade, E.H.A.; da Silva, J.K.R.; Maia, J.G.S. Essential oil composition of Croton palanostigma Klotzsch from north Brazil. J. Braz. Chem. Soc. 2009, 20, 1188-1192.

17. Santos, H.S.; Furtado, E.F.; Bertini, L.M.; Bandeira, P.N.; Albuquerque, M.R.J.R.; Menezes, J.E.S.A.; Trevisan, M.T.S.; Lemos, T.L.G. Chemical composition and cholinesterase inhibition of essential oils of three chemotypes from Croton zehntneri. Rev. Latinoam. Quim. 2010, 38, 45-51.

18. De Almeida, T.S.; Rocha, J.B.T.; Rodrigues, F.F.G.; Campos, A.R.; da Costa, J.G.M. Chemical composition, antibacterial and antibiotic modulatory effect of Croton campestris essential oils. Ind. Crop. Prod. 2013, 44, 630-633.

19. Secco, R.S.; Cordeiro, I.; Senna-Vale, L.; Sales, M.F.; Lima, L.R.; Medeiros, D.; sá Haiad, B.; de Oliveira, A.S.; Caruzo, M.B.R.; Carneiro-Torres, D.; et al. An overview of recent taxonomic studies on Euphorbiaceae s.l. in Brazil. Rodriguésia 2012, 63, 227-242.

20. Silva, J.S.; Sales, M.F.; Gomes, A.P.S.; Carneiro-Torres, D.S. Synopsis of the species of Croton L. (Euphorbiaceae) in Pernambuco state, Brasil. Acta Bot. Bras. 2010, 24, 441-453.

21. Randau, K.P. Estudo Farmacognóstico (Farmacobotânico e Farmacoquímico) e Atividade Biológica do Croton Rhamnifolius H.B.K. e Croton Rhamnifolioides Pax \& Hoffm. (Euphorbiaceae). Master's Thesis, Universidade Federal de Pernambuco, Recife, Brazil, February 2001.

22. Randau, K.P.; Florêncio, D.C.; Ferreira, C.P.; Xavier, H.S. Estudo farmacognóstico de Croton rhamnifolius H.B.K. e Croton rhamnifolioides Pax \& Hoffm. (Euphorbiaceae). Rev. Bras. Farmacogn. 2004, 14, 89-96.

23. World Health Organization. Dengue: Guidelines for Diagnosis Treatment, Prevention and Control; WHO Press: Geneva, Switzerland, 2009; pp. 3-87.

24. Rodríguez, M.M.; Bisset, J.; Ruiz, M.; Soca, A. Cross-resistance to pyrethroid and organophosphorus insecticides induced by selection with temephos in Aedes aegypti (Diptera: Culicidae) from Cuba. J. Med. Entomol. 2002, 39, 882-888. 
25. García, G.P.; Flores, A.E.; Fernández-Salas, I.; Saavedra-Rodríguez, K.; Reyes-Solis, G.; Lozano-Fuentes, S.; Guillermo Bond, J.; Casas-Martínez, M.; Ramsey, J.M.; García-Rejón, J.; et al. Recent rapid rise of a permethrin knock down resistance allele in Aedes aegypti in México. PLoS Negl. Trop. Dis. 2009, 3, e531.

26. Melo-Santos, M.A.V.; Varjal-Melo, J.J.M.; Araújo, A.P.; Gomes, T.C.S.; Paiva, M.H.S.; Regis, L.N.; Furtado, A.F.; Magalhaes, T.; Macoris, M.L.G.; Andrighetti, M.T.M.; et al. Resistance to the organophosphate temephos: Mechanisms, evolution and reversion in an Aedes aegypti laboratory strain from Brazil. Acta Trop. 2010, 113, 180-189.

27. Tantely, M.L.; Tortosa, P.; Alout, H.; Berticat, C.; Berthomieu, A.; Rutee, A.; Dehecq, J.-S.; Makoundou, P.; Labbé, P.; Pasteur, N.; et al. Insecticide resistance in Culex pipiens quinquefasciatus and Aedes albopictus mosquitoes from La Réunion Island. Insect Biochem. Mol. Biol. 2010, 40, 317-324.

28. Ocampo, C.B.; Salazar-Terreros, M.J.; Mina, N.J.; McAllister, J.; Brogdon, W. Insecticide resistance status of Aedes aegypti in 10 localities in Colombia. Acta Trop. 2011, 118, 37-44.

29. Vontas, J.; Kioulos, E.; Pavlidi, N.; Morou, E.; della Torre, A.; Ranson, H. Insecticide resistance in the major dengue vectors Aedes albopictus and Aedes aegypti. Pestic. Biochem. Physiol. 2012, 104, 126-131.

30. Carvalho, A.F.U.; Melo, V.M.M.; Craveiro, A.A.; Machado, M.I.L.; Bantim, M.B.; Rabelo, E.F. Larvicidal activity of the essential oil from Lippia sidoides Cham. against Aedes aegypti Linn. Mem. Inst. Oswaldo Cruz 2003, 98, 569-571.

31. Cavalcanti, E.S.B.; de Morais, S.M.; Lima, M.A.A.; Santana, E.W.P. Larvicidal activity of essential oils from Brazilian plants against Aedes aegypti L. Mem. Inst. Oswaldo Cruz 2004, 99, 541-544.

32. Santos, R.P.; Nunes, E.P.; Nascimento, R.F.; Santiago, G.M.P.; Menezes, G.H.A.; Silveira, E.R.; Pessoa, O.D.L. Chemical composition and larvicidal activity of the essential oils of Cordia leucomalloides and Cordia curassavica from the northeast of Brazil. J. Braz. Chem. Soc. 2006, 17, 1027-1030.

33. Kovendan, K.; Murugan, K.; Mahesh Kumar, P.; Thiyagarajan, P.; William, S.J. Ovicidal, repellent, adulticidal and field evaluations of plant extract against dengue, malaria and filarial vectors. Parasitol. Res. 2013, 112, 1205-1219.

34. Wang, Z.; Kim, J.-R.; Wang, M.; Shu, S.; Ahn, Y.-J. Larvicidal activity of Cnidium monnieri fruit coumarins and structurally related compounds against insecticide-susceptible and insecticide-resistant Culex pipiens pallens and Aedes aegypti. Pest Manag. Sci. 2012, 68, 1041-1047.

35. Senthilkumar, A.; Jayaraman, M.; Venkatesalu, V. Chemical constituents and larvicidal potential of Feronia limonia leaf essential oil against Anopheles stephensi, Aedesaegypti and Culex quinquefasciatus. Parasitol. Res. 2013, 112, 1337-1342.

36. Navarro, D.M.A.F.; da Silva, P.C.B.; da Silva, M.F.R.; Napoleao, T.H.; Paiva, P.M.G. Larvicidal activity of plant and algae extracts, essential oils and isolated chemical constituents against Aedes aegypti. Nat. Prod. J. 2014, 3, 268-291.

37. Dória, G.A.A.; Silva, W.J.; Carvalho, G.A.; Alves, P.B.; Cavalcanti, S.C.H. A study of the larvicidal activity of two Croton species from northeastern Brazil against Aedes aegypti. Pharm. Biol. 2010, 48, 615-620. 
38. Camurça-Vasconcelos, A.L.F.; Bevilaqua, C.M.L.; Morais, S.M.; Maciel, M.V.; Costa, C.T.C.; Macedo, I.T.F.; Oliveira, L.M.B.; Braga, R.R.; Silva, R.A.; Vieira, L.S. Anthelmintic activity of Croton zehntneri and Lippia sidoides essential oils. Vet. Parasitol. 2007, 148, 288-294.

39. De Lima, G.P.G.; de Souza, T.M.; de Paula Freire, G.; Farias, D.F.; Cunha, A.P.; Ricardo, N.M.P.S.; de Morais, S.M.; Carvalho, A.F.U. Further insecticidal activities of essential oils from Lippia sidoides and Croton species against Aedes aegypti L. Parasitol. Res. 2013, 112, 1953-1958.

40. Morais, S.M.; Cavalcanti, E.S.B.; Bertini, L.M.; Oliveira, C.L.L.; Rodrigues, J.R.B.; Cardoso, J.H.L. Larvicidal activity of essential oils from Brazilian Croton species against Aedes aegypti L. J. Am. Mosq. Control Assoc. 2006, 22, 161-164.

41. Torres, M.C.M.; Assunção, J.C.; Santiago, G.M.P.; Andrade-Neto, M.; Silveira, E.R.; Costa-Lotufo, L.V.; Bezerra, D.P.; Marinho Filho, J.D.B.; Viana, F.A.; Pessoa, O.D.L. Larvicidal and nematicidal activities of the leaf essential oil of Croton regelianus. Chem. Biodivers. 2008, 5, 2724-2728.

42. Misharina, T.A.; Polshkov, A.N.; Ruchkina, E.L.; Medvedeva, I.B. Changes in the composition of the essential oil of marjoram during storage. Appl. Biochem. Microbiol. 2003, 39, 311-316.

43. El-Nikeety, M.M.A.; el-Akel, A.T.M.; el-Hady, M.M.I.A.; Badei, A.Z.M. Changes in physical properties and chemical constituents of parsley herb volatile oil during storage. Egypt. J. Food Sci. 2000, 26, 35-49.

44. Turek, C.; Stintzing, F.C. Impact of different storage conditions on the quality of selected essential oils. Food Res. Int. 2012, 46, 341-353.

45. Wise, M.L.; Urbansky, M.; Helms, G.L.; Coates, R.M.; Croteau, R. Syn stereochemistry of cyclic ether formation in 1,8-cineole biosynthesis catalyzed by recombinant synthase from Salvia officinalis. J. Am. Chem. Soc. 2002, 124, 8546-8547.

46. Weyerstahl, P.; Krohn, K. Structure-Odor correlation-IX from 1,8-cineole to sesquicineol—Change of odor with structure. Tetrahedron 1990, 46, 3503-3514.

47. Santos, G.K.N.; Dutra, K.A.; Barros, R.A.; da Câmara, C.A.G.; Lira, D.D.; Gusmão, N.B.; Navarro, D.M.A.F. Essential oils from Alpinia purpurata (Zingiberaceae): Chemical composition, oviposition deterrence, larvicidal and antibacterial activity. Ind. Crop. Prod. 2012, 40, 254-260.

48. Perumalsamy, H.; Kim, N.-J.; Ahn, Y.-J. Larvicidal activity of compounds isolated from Asarum heterotropoides against Culex pipiens pallens, Aedes aegyti and Ochlerotatus togoi (Diptera: Culicidade). J. Med. Entomol. 2009, 46, 1420-1423.

49. Cheng, S.-S.; Huang, C.-G.; Chen, Y.-J.; Yu, J.-J.; Chen, W.-J.; Chang, S.-T. Chemical compositions and larvicidal activities of leaf essential oils from two Eucaliptus species. Bioresour. Technol. 2009, $100,452-456$.

50. Pontual, E.V.; Napoleão, T.H.; Dias de Assis, C.R.; de Souza Bezerra, R.; Xavier, H.S.; Navarro, D.M.A.F.; Coelho, L.C.B.B.; Paiva, P.M.G. Effect of Moringa oleifera flower extract on larval trypsin and acethylcholinesterase activities in Aedes aegypti. Arch. Insect Biochem. Physiol. 2012, 79, 135-152.

51. Napoleão, T.H.; Pontual, E.V.; de Albuquerque Lima, T.; de Lima Santos, N.D.; Sá, R.A.; Coelho, L.C.B.B.; Navarro, D.M.A.F.; Paiva, P.M.G. Effect of Myracrodruon urundeuva leaf lectin on survival and digestive enzymes of Aedes aegypti larvae. Parasitol. Res. 2012, 110, 609-616. 
52. Blenau, W.; Rademacher, E.; Baumann, A. Plant essential oils and formamidines as insecticides/acaricides: What are the molecular targets? Apidologie 2012, 43, 334-347.

53. Kostyukovsky, M.; Rafaeli, A.; Demchenko, N.; Shaaya, E. Activation of actopaminergic receptors by essential oil isolated from aromatic plants: Possible mode of action against insect pests. Pest Manag. Sci. 2002, 58, 1101-1106.

54. Enam, E.E. Molecular and pharmacological analysis of an octopamine receptor from American cockroach and fruitfly in response to plant essential oils. Arch. Insect Biochem. Physiol. 2005, 59, 161-171.

55. Khanikor, B.; Parida, P.; Yadav, R.N.S.; Bora, D. Comparative mode of action of some terpene compounds against octopamine receptor and acetyl cholinesterase of mosquito and human system by the help of homology modeling and Docking studies. J. Appl. Pharm. Sci. 2013, 3, 6-12.

56. Anderson, J.A.; Coats, J.R. Acetylcholinesterase inhibition by nootkatone and carvacrol in arthropods. Pestic. Biochem. Physiol. 2012, 102, 124-128.

57. Bentley, M.D.; Day, J.F. Chemical ecology and behavioral aspects of mosquito oviposition. Annu. Rev. Entomol. 1989, 34, 401-421.

58. Autran, E.S.; Neves, I.A.; da Silva, C.S.B.; Santos, G.K.N.; da Câmara, C.A.G.; Navarro, D.M.A.F. Chemical composition, oviposition deterrent and larvicidal activities against Aedes aegypti of essential oils from Piper marginatum Jacq. (Piperaceae). Bioresour. Technol. 2009, 100, 2284-2288.

59. Siriporn, P.; Mayura, S. The effects of herbal essential oils on the oviposition-deterrent and ovicidal activities of Aedes aegypti (Linn.), Anopheles dirus (Peyton and Harrison) and Culex quinquefasciatus (Say). Trop. Biomed. 2012, 29, 138-150.

60. Van den Dool, H.; Dec. Kratz, P. A generalization of the retention index system including linear programmed gas-liquid partition chromatography. J. Chromatogr. A 1963, 11, 463-471.

61. Adams, R.P. Identification of Essential Oil Compounds by Gas Chromatography and Mass Spectrometry, 4th ed.; Allured Publishing: Carol Stream, IL, USA, 2007.

62. Navarro, D.M.A.F.; de Oliveira, P.E.S.; Potting, R.P.J.; Brito, A.C.; Fital, S.J.F.; Sant'Ana, A.E.G. The potential attractant or repellent effects of different water types on oviposition in Aedes aegypti L. (Dipt., Culicidae). J. Appl. Entomol. 2003, 127, 46-50.

63. Lowry, O.H.; Rosebrough, N.J.; Farr, A.L.; Randall, R.J. Protein measurement with the Folin phenol reagent. J. Biol. Chem. 1951, 193, 265-275.

Sample Availability: Samples of the compounds $\alpha$-Phellandrene and 1,8-Cineole are available from the authors.

(C) 2014 by the authors; licensee MDPI, Basel, Switzerland. This article is an open access article distributed under the terms and conditions of the Creative Commons Attribution license (http://creativecommons.org/licenses/by/4.0/). 